\title{
EFEKTIVITAS DAN EFISIENSI SISTEM INVENTARIS LABORATOIUM ONLINE
}

\author{
Riswanto \\ Program Studi Pendidikan Fisika, Universitas Muhammadiyah Metro \\ Email: rumbiariswan@gmail.com
}

Diterima: 14 Agustus 2019. Disetujui: 16 September 2019.

\begin{abstract}
Abstrak
Era globalisasi disruptive innovation yang ditandai dengan digitalisasi seluruh aspek kehidupan termasuk pendidikan yang bebasis pada big data. Laboratorium merupakan standar minimal yang harus dimiliki penyelenggara pendidikan, tujuannya yaitu untuk mendukung aktivitas pembelajaran sains.Sistem laboratorium telah dikembangkan secara online perlu ditinjau nilai efektivitas dan efisiensinya. Metode penelitian dilakukan dengan triangulasi data dan teknik snowball berupa data kuantitatif dan data kualitatif. Hasil yang diperoleh bahwa efektivitas sistem laboratorium online memberikan kemudahan dalam pelaksanaan kegiatan praktikum dan kemudahan komunikasi bagi para pengguna laboratorium. Sedangkam efisiensi sistem inventaris laboratorium fisika online yaitu waktu yang diperlukan 6 kali lebih cepat memanfaatkan sistem inventaris laboratorium onlinebila dibandingkan dengan sistem manual.
\end{abstract}

Kata Kunci: Efektivitas, Efisiensi, Laboratorium Fisika.

\begin{abstract}
The era of disruptive innovation globalization is marked by the digitalization of all aspects of life, including education-based on big data. The laboratory is a minimum standard that must be held by education providers, and the goal is to support science learning activities. Laboratory systems that have been developed online need to be reviewed for their effectiveness and efficiency values. The research method was carried out by data triangulation and snowball techniques in the form of quantitative data and qualitative data. The results obtained that the effectiveness of the online laboratory system provides convenience in carrying out practical activities and ease of communication for laboratory users. As efficient as the online physics laboratory inventory system is, it takes six times faster to utilize an online laboratory inventory system when compared to a manual mode.

Keywords:Effectiveness, Efficiency, Physics Laboratory.
\end{abstract}

\section{PENDAHULUAN} Era digitalisasi teknologi dalam istilah disruptive innovation. berbagai bidang yang menekankan Merupakan suatu tantangan yang pada pola ekonomi digital, big data, harus dihadapi dengan mem- social digital/media social, robotika, dan aspek lain yang dikenal dengan 
persiapkan sumber daya manusia yang unggul, kreatif, dan inovatif. Oleh karena itu, Pemerintah Indonesia membentuk badan riset nasional terkait blue print atau cetak biru pembangunan industri menuju revolusi industri 4.0. Revolusi industri 4.0 merupakan sistem yang mengintegrasikan dunia online dengan produksi industri. Efek revolusi tersebut adalah meningkatnya efisiensi produksi karena menggunakan teknologi digital dan otomatisasi, serta perubahan komposisi lapangan kerja. Hal ini menandakan bahwa akan ada kebutuhan tenaga kerja baru yang tumbuh dan berkembang pesat, sekaligus ada kebutuhan tenaga kerja lama yang akan tergantikan oleh tenaga mesin.

Upaya pemerintah dalam mempersiapkan Sumber daya manusia dalam menghadapi era $4.0 \mathrm{di}$ wujudkan melalui Peraturan Pemerintah No. 19 tahun 2005 tentang Standar Nasional Pendidikan (SNP) menyatakan bahwa: Perlu adanya standar mutu tolak ukur minimal untuk menilai tingkat mutu penyediaan, pemanfaatan, pe- meliharaan dan pengembangan sarana dan prasarana yang tersedia pada setiap perguruan tinggi.

Sarana dan prasarana pembelajaran merupakan hal yang sangat penting sebagai penunjang proses pembelajaran. Sarana pembelajaran antara lain perabot, media pendidikan, peralatan pendidikan, buku dan sumber belajar lainnya, bahan habis pakai, serta perlengkapan lain yang diperlukan untuk proses pembelajaran. Perguruan tinggi juga wajib memiliki prasarana yaitu seperti ruang kelas, ruang pimpinan satuan pendidikan, ruang pendidik, ruang tata usaha, ruang perpustakaan, ruang laboratorium, ruang unit produksi, kantin, instalasi daya dan jasa, tempat berolahraga, tempat beribadah, tempat bermain, tempat berkreasi, dan ruang/tempat lain yang diperlukan untuk menunjang proses pembelajaran (Presiden Republik Indonesia, 2005).

Peranan laboratorium dalam menunjang proses pembelajaran dapat dioptimalkan dalam menunjang kegiatan praktikum agar dapat berjalan secara efisien (Suseno, 2017). Presiden Republik Indonesia. 
(2005) melalui peraturan pemerintah Republik Indonesia nomor 19 tahun 2005 tentang standar nasional pendidikan dan Menteri Pendidikan Nasional (2007), melalui Peraturan Menteri Pendidikan Nasional Republik Indonesia Nomor 24 Tahun 2007 menyatakan bahwa ruang laboratorium merupakan salah satu sarana standar minimal harus dimiliki oleh lembaga penyelenggara pendidikan baik itu sekolah maupun perguruan tinggi. Laboratorium dapat diartikan sebagai sarana ruangan yang digunakan untuk memfasilitasi kegiatan ilmiah seperti praktikum. Laboratorium merupakan tempat yang penting dimana pengetahuan baru dihasilkan dan divalidasikan dalam bentuk eksperimen ilmiah (Riswanto \& Dewi, 2017). Pada tabel 1 telah disajikan data hasil survey awal mengenai efisiensi waktu dalam pelayanan kegiatan di laboratorium.

Tabel 1. Survey pelayanan Laboratorium

\begin{tabular}{|c|c|c|c|}
\hline No & $\begin{array}{l}\text { Aspek yang } \\
\text { Diamati }\end{array}$ & Indikator & $\begin{array}{l}\text { Waktu yang } \\
\text { Dibutuhkan }\end{array}$ \\
\hline \multirow{4}{*}{1.} & \multirow{4}{*}{$\begin{array}{l}\text { Waktu Persiapan/ } \\
\text { Peminjaman Alat } \\
\text { dan Bahan }\end{array}$} & $\begin{array}{l}\text { Mengisi form peminjaman dan melakukan } \\
\text { pemesanan alat/bahan }\end{array}$ & 3 menit \\
\hline & & $\begin{array}{l}\text { Pencarian ketersediaan alat/bahan } \\
\text { menggunakan kode/nama }\end{array}$ & 15 menit \\
\hline & & Mengetahui tempat/keberadaan alat/bahan & 5 menit \\
\hline & & Mengecek kondisi alat/bahan & 4 menit \\
\hline \multirow{4}{*}{2.} & \multirow{4}{*}{$\begin{array}{l}\text { Waktu Pengembalian } \\
\text { Alat, Bahan dan } \\
\text { Barang }\end{array}$} & $\begin{array}{l}\text { Mengecek kondisi alat/bahan sebelum } \\
\text { disimpan }\end{array}$ & 8 menit \\
\hline & & Mencatat dan mendata alat/bahan yang rusak & 3 menit \\
\hline & & Mengembalikan alat/bahan sesuai kode & 10 menit \\
\hline & & $\begin{array}{l}\text { Menyusun kembali alat/bahan ke tempat } \\
\text { semula }\end{array}$ & 8 menit \\
\hline & & Jumlah & 56 menit \\
\hline & & Rata-rata & 7 menit \\
\hline
\end{tabular}

Hasil survey menggunakan angket dan observasi laboratorium di pendidikan Fisika Universitas Muhammadiyah Metro menunjukan hasil sebagai berikut: 1) laboratorium fisika UM Metro telah memiliki SOP dalam pengelolaan administrasi peminjaman alat dan bahan, 2) Masih ditemui beberapa alat yang belum memiliki kode dan belum tersimpan pada lemari, 3) laboratorium telah memilki struktur pengelolaan 
laboratorium yang sesuai standar yaitu memiliki kepala laboratorium, laboran dan teknisi, dan staf laboran. Salah satu cara untuk mencapai tujuan pembelajaran yang sejalan dengan pembelajaran abad ke-21 yang juga merupakan bentuk revolusi industri 4.0 adalah pembelajaran berbasis laboratorium dan integrasi penggunaan TI dalam pembelajaran sains. Selain itu, dalam meningkatkan pengelolaan laboratorium yang efektif dan efisien maka dikembangkan inventaris laboratorium fisika secara online. Pemanfaatan teknologi sangat diperlukan di dalam sistem inventaris laboratorium, dengan demikian laboran dan semua pihak akan dimudahkan dalam mencari dan mengontrol alat dan bahan yang ada di laboratorium. Menurut Putri (2013), sistem inventaris laboratorium sangat diperlukan karena dapat memberikan kemudahan dalam melakukan inventarisasi. Peminjaman pada sistem ini baru sebatas dekstop aplikasi berbasis sistem web dan belum berbasis Local Area". hasil penelitian tersebut, menunjukan pengembangan sistem informasi inventaris digital berbasis WAN
(Wide Area Network) yang mampu memberikan cara pengelolaan informasi yang efektif dan efisien.

Inventaris berbasis WEB ini dapat memberikan pelayanan peminjaman barang untuk siswa maupun bagian yang terkait dengan menghasilkan sebuah informasi perawatan dan dokumentasi yang digunakan untuk data barang dan perawatan barang (Hadibin, 2012).

Berdasarkan latar belakang maka telah dikembangkan sistem inventaris laboratorium pendidikan fisika secara online. Namun walaupun demikian perlu ditinjau efisiensi dan efektivitas mendalam mengenai penggunaan sistem inventaris laboratorium fisika secara online. Tujuannya untuk menemukan kelemahan dan kekuranganya, untuk kemudian ditentukan solusi dan upaya perbaikan untuk mengatasi hal tersebut.

Efektivitas menurut Effendy (2008), adalah komunikasi yang prosesnya mencapai tujuan yang direncanakan sesuai dengan biaya yang dianggarkan, waktu yang ditetapkan dan jumlah personil yang ditentukan. Berdasarkan devinisi 
Riswanto - Efektivitas Dan Efisiensi Sistem Inventaris...

tersebut, indikator efektivitas dalam hal ini diartikan sebagai tercapainya sasaran atau tujuan yang telah ditentukan sebelumnya merupakan sebuah pengukuran dimana suatu target telah tercapai sesuai dengan apa yang telah direncanakan. Menurut Susanto (2005), efektivitas merupakan daya pesan untuk mempengaruhi atau tingkat kemampuan pesan-pesan untuk mempengaruhi. Berdasarkan pengertian tersebut, efektivitas bisa diartikan sebagai suatu pengukuran akan tercapainya tujuan yang telah direncanakan sebelumnya secara matang. Efektivitas merupakan suatu ukuran yang memberikan gambaran seberapa jauh target dapat tercapai.

Efisien menurut bahasa adalah tepat atau sesuai untuk mengerjakan (menghasilkan) sesuatu (dengan tidak membuang-buang waktu, tenaga, biaya). Sementara Rahardjo (2011) mengemukakan mengartikan efisiensi adalah komponen-komponen input yang digunakan seperti waktu, tenaga dan biaya dapat dihitung penggunaannya dan tidak berdampak pada pemborosan atau pengeluaran yang tidak berarti. Setiap kegiatan praktikum harus mempertimbangkan aspek efesien. Hal ini dikarenakan efisiensi merupakan aspek yang sangat penting dalam manajemen sekolah karena sekolah pada umumnya dihadapkan pada kelengkapan sumber dana dan secara langsung terpengaruh terhadap kegiatan (Mutohar, 2013).

\section{METODE}

Metode pengumpulan data dalam penelitian ini menggunakan teknik snowball dan triangulasi sumber data dengan menggunakan instrumen berupa lembar angket, lembar wawancara dan lembar observasi. Lembar wawancara diperlukan untuk memperoleh informasi penggunaan laboratorium dari pengguna yaitu praktikan, dosen, laboran dan mahasiswa lainnya.

Lembar angket berupa kuisioner digunakan sebagai pertanyaan terbuka yang diberikan kepada para mahasiswa dan dosen menggenai penggunaan laboratorium. Sedangkan lembar observasi diperlukan untuk mencatat waktu yang dibutuhkan dalam kegiatan pelayanan di laboratorium. Data yang diperoleh 
berupa data kualitatif dan data pemesanan kebutuhan alat praktikum kuantitatif, kedua data tersebut di laboratorium. Bagi laboran kemudian diolah dan dianalisis keberadaan laboratorium fisika secara dengan membandingkan hasil dari online mampu mempermudah setiap sumber data yang telah pekerjaan laboran untuk melacak diperoleh.

\section{HASIL DAN PEMBAHASAN}

Implementasi laboratorium secara online mendapat respon yang positif dari para pengguna baik mahasiswa sebagai praktikan maupun laboran sebagai petugas pengelola. Ditinjau dari aspek efektivitas bahwa keberadaan laboratorium fisika secara online dapat memberikan kemudahan untuk berkomunikasi antara asisten, dosen dan laboran. Bentuk komunikasi yang dimaksud yaitu mahasiswa dapat dengan mudah mengetahui informasi data alat dan bahan yang dimiliki laboratorium. keberadaan laboratorium. Cara yang dapat dilakukan yaitu dengan menginput nama pada kolom search kemudian secara otomatis akan muncul informasi mengenai keberadaan dan kondisi alat laboratorium. Sedangkan bagi staf administrasi juga memudahkan dalam memantau sirkulasi penggunaan alat dan bahan di laboratorium pendidina fisika. Hasil uji coba implementasi untuk mengukur efektivitas penggunaan laboratorium dilihat dengan cara memberikan angket kepada praktikan, dan laboran di laboratorium pendidikan fisika tampak pada tabel 2 .

Serta memudahkan dalam melakukan

Tabel 2. Uji angket efektivitas penggunaan Lab fisika online

\begin{tabular}{|c|c|c|}
\hline Aspek & Indikator & Persentase capaian \\
\hline \multirow[t]{2}{*}{$\begin{array}{l}\text { Effectiveness } \\
\text { (Efektivitas) }\end{array}$} & $\begin{array}{l}\text { Mengurangi waktu yang dibutuhkan untuk mencari } \\
\text { alat, bahan dan barang }\end{array}$ & 88 \\
\hline & $\begin{array}{l}\text { Memberikan kemudahan untuk berkomunikasi antara } \\
\text { asisten, dosen dengan laboran }\end{array}$ & 88 \\
\hline
\end{tabular}

Informasi yang diperoleh pada tabel 2 merasakan bahwa keberadaan yaitu bahwa sebanyak $88 \%$ pengguna inventaris laboratorium secara online 
dapat mengurangi waktu yang melakukan pemesanan alat, bahan dan dibutuhkan dalam mencari alat, bahan barang laboratorium. Maka guna dan barang Angka ini menunjukan memperkuat informasi data di atas bahwa pengguna laboratorium merasa dilakukan pengujian dengan terbantu dalam mencari alat dan menggunakan lembar observasi. Uji bahan di laboratorium. Selain itu juga, coba penggunaan laboratorium sebanyak $88 \%$ pengguna menyatakan dilakukan sebanyak tiga kali seperti bahwa sistem inventaris laboratorium secara online memberikan kemudahan tampak pada tabel 3. Efisiensi yang untuk berkomunikasi antara asisten, dosen, dengan laboran dalam dikaji adalah waktu peminjaman/persiapan dan waktu pengembalian alat-alat laboratorium.

Tabel 3.Hasil Observasi Waktu

\begin{tabular}{|c|c|c|c|c|c|c|c|}
\hline No & Aspek & Indikator & $\begin{array}{c}\text { Uji } \\
\text { Coba } 1\end{array}$ & $\begin{array}{c}\text { Uji } \\
\text { Coba } 2\end{array}$ & $\begin{array}{c}\text { Uji Coba } \\
\mathbf{3}\end{array}$ & Rata-rata & $\begin{array}{l}\text { Rata- } \\
\text { rata per } \\
\text { Aspek }\end{array}$ \\
\hline \multirow{4}{*}{1.} & \multirow{4}{*}{$\begin{array}{l}\text { Waktu } \\
\text { Persiapan/ } \\
\text { Peminjaman } \\
\text { Alat dan Bahan }\end{array}$} & $\begin{array}{l}\text { Mengisi form } \\
\text { peminjaman dan } \\
\text { melakukan } \\
\text { pemesanan } \\
\text { alat/bahan }\end{array}$ & $\begin{array}{l}2 \text { menit } \\
17 \text { detik }\end{array}$ & $\begin{array}{l}1 \text { menit } \\
30 \text { detik }\end{array}$ & $\begin{array}{l}1 \text { menit } \\
34 \text { detik }\end{array}$ & $\begin{array}{l}1 \text { menit } 8 \\
\text { detik }\end{array}$ & \multirow{4}{*}{$\begin{array}{l}1 \text { menit } \\
2 \text { detik }\end{array}$} \\
\hline & & $\begin{array}{l}\text { Pencarian } \\
\text { ketersediaan alat/ } \\
\text { bahan } \\
\text { menggunakan } \\
\text { kode/ nama }\end{array}$ & $\begin{array}{l}1 \text { menit } \\
3 \text { detik }\end{array}$ & $\begin{array}{l}2 \text { menit } 4 \\
\text { detik }\end{array}$ & $\begin{array}{l}2 \text { menit } \\
5 \text { detik }\end{array}$ & $\begin{array}{l}1 \text { menit } 6 \\
\text { detik }\end{array}$ & \\
\hline & & $\begin{array}{l}\text { Mengetahui tempat/ } \\
\text { keberadaan } \\
\text { alat/bahan }\end{array}$ & $\begin{array}{l}1 \text { menit } \\
8 \text { detik }\end{array}$ & $\begin{array}{l}1 \text { menit } 6 \\
\text { detik }\end{array}$ & $\begin{array}{l}1 \text { menit } \\
30 \text { detik }\end{array}$ & $\begin{array}{l}1 \text { menit } 2 \\
\text { detik }\end{array}$ & \\
\hline & & $\begin{array}{l}\text { Mengecek kondisi } \\
\text { alat/bahan }\end{array}$ & 3 menit & $\begin{array}{l}1 \text { menit } \\
30 \text { detik }\end{array}$ & $\begin{array}{l}1 \text { menit } \\
10 \text { detik }\end{array}$ & $\begin{array}{l}1 \text { menit } 9 \\
\text { detik }\end{array}$ & \\
\hline \multirow{4}{*}{2.} & \multirow{4}{*}{$\begin{array}{l}\text { Waktu } \\
\text { Pengembalian } \\
\text { Alat dan Bahan }\end{array}$} & $\begin{array}{l}\text { Mengecek kondisi } \\
\text { alat/bahan sebelum } \\
\text { disimpan }\end{array}$ & $\begin{array}{l}2 \text { menit } \\
15 \text { detik }\end{array}$ & $\begin{array}{l}2 \text { menit } 4 \\
\text { detik }\end{array}$ & $\begin{array}{l}1 \text { ment } \\
20 \text { detik }\end{array}$ & $\begin{array}{l}1 \text { menit } 9 \\
\text { detik }\end{array}$ & \multirow{4}{*}{1 menit } \\
\hline & & $\begin{array}{l}\text { Mencatat dan } \\
\text { mendata alat/bahan } \\
\text { yang rusak }\end{array}$ & 0 detik & 0 detik & 36 detik & 2 detik & \\
\hline & & $\begin{array}{l}\text { Mengembalikan } \\
\text { alat/bahan sesuai } \\
\text { kode }\end{array}$ & $\begin{array}{l}1 \text { menit } \\
12 \text { detik }\end{array}$ & $\begin{array}{l}1 \text { menit } \\
46 \text { detik }\end{array}$ & $\begin{array}{l}1 \text { menit } \\
5 \text { detik }\end{array}$ & $\begin{array}{l}1 \text { menit } 3 \\
\text { detik }\end{array}$ & \\
\hline & & $\begin{array}{l}\text { Menyusun kembali } \\
\text { alat/bahan ke } \\
\text { tempat semula }\end{array}$ & $\begin{array}{l}1 \text { menit } \\
12 \text { detik }\end{array}$ & 2 menit & $\begin{array}{l}2 \text { menit } \\
34 \text { detik }\end{array}$ & $\begin{array}{l}1 \text { menit } 9 \\
\text { detik }\end{array}$ & \\
\hline
\end{tabular}


Riswanto - Efektivitas Dan Efisiensi Sistem Inventaris...

Efisiensi dalam penelitian ini pengembalian alat/bahan sesuai dilihat dari ketepatan waktu jadwal praktikum.Hasil uji coba pelaksanaan persiapan peminjaman sebelum dan sesudah pengembangan dan pengembalian alat/bahan.Uji coba produk dapat dilihat pada tabel 4. pada persiapan peminjaman dan

Tabel 4.Hasil Uji Coba Sebelum dan Sesudah penggunaan laboratorium online

\begin{tabular}{|c|c|c|c|}
\hline \multirow{2}{*}{ No. } & \multirow{2}{*}{ Indikator } & \multicolumn{2}{|c|}{ Waktu yang Dibutuhkan } \\
\hline & & Sebelum & Sesudah \\
\hline 1. & $\begin{array}{l}\text { Mengisi form peminjaman dan melakukan } \\
\text { pemesanan alat/bahan }\end{array}$ & 3 menit & 1 menit 8 detik \\
\hline 2. & $\begin{array}{l}\text { Pencarian ketersediaan alat/bahan } \\
\text { menggunakan kode/Nama }\end{array}$ & 15 menit & 1 menit 6 detik \\
\hline 3. & Mengetahui tempat/keberadaan alat/bahan & 5 menit & 1 menit 2 detik \\
\hline 4. & Mengecek kondisi alat/bahan & 4 menit & 1 menit 9 detik \\
\hline 5. & $\begin{array}{l}\text { Mengecek kondisi alat/bahan sebelum } \\
\text { disimpan }\end{array}$ & 8 menit & 1 menit 9 detik \\
\hline 6. & Mencatat dan mendata alat/bahan yang rusak & 3 menit & 2 detik \\
\hline 7. & Mengembalikan alat/bahan sesuai kode & 10 menit & 1 menit 3 detik \\
\hline 8. & $\begin{array}{l}\text { Menyusun kembali alat/bahan ke tempat } \\
\text { semula }\end{array}$ & 8 menit & 1 menit 9 detik \\
\hline & Jumlah & 56 menit & 8 menit \\
\hline & Rata-rata & 7 menit & 1 menit \\
\hline
\end{tabular}

Berdasarkan tabel 2 hasil uji coba sesudah pengembangan produk dapat dikemukakan bahwa pelaksanaan persiapan peminjaman dan pengembalian alat/bahan tidak mengganggu pelaksanaan praktikum di laboratorium. Waktu persiapan/ peminjaman alat/bahan dan waktu mengembalikan serta merapikan kembali peralatan yang telah digunakan hanya memerlukan waktu rata-rata 1 menit. Data tersebut menunjukan bahwa sistem inventaris laboratorium fisika secara online lebih efisien sebesar $600 \%$ atau sama dengan 6 kali lebih efisien daripada sistem inventaris laboratorium secara manual.

\section{KESIMPULAN DAN SARAN}

\section{Kesimpulan}

Keefektifan sistem inventaris laboratorium fisika secara online memberikan kemudahan bagi para pengguna yaitu laboran, kepala laboratorium, praktikan, staff dan 
Riswanto - Efektivitas Dan Efisiensi Sistem Inventaris...

asisten laboratorium, dalam berkomunikasi terkait pemesanan dan pengecekan keberadaan alat-alat laboratorium. Sebanyak $88 \%$ pengguna merasakan dampak positif keberadaan sistem inventaris laboratorium fisika secara online. Sedangkan efisiensi penggunaan laboratorium fisika secara online dengan meninjau waktu penggunaan laboratorium mulai dari proses pemesanan, peminjaman, kegiatan praktikum hingga proses pengembalian dan penataan alat. Efisiensi waktu yang diperlukan 6 kali lebih cepat bila dibandingkan dengan sistem inventaris laboratorim fisika secara manual.

\section{Saran}

Saran bagi penelitian selanjutnya yaitu perlu dilakukan pengembangan sistem inventaris online lanjutan pada level sekolah pendidikan menegah maupun level pendidikan dasar.

\section{DAFTAR PUSTAKA}

Aththibby, A., Lubis, S., \& Ardiyanti, Y. (2019, July). Tpack as Innovation of Learning Science Laboratory of Indonesia. In 6th International Conference on Educational Research and Innovation (ICERI 2018).
Atlantis Press.

Effendy, O. U. (2008). Dinamika Komunikasi. Bandung: PT. RemajaRosdakarya.

Hadibin, M. M. (2012). Sistem informasi perawatan dan inventaris laboratorium pada SMK Negeri 1 Rembang berbasis web. Speed-Sentra Penelitian Engineering dan Edukasi, 3(4).

Mutohar, P. M. (2013). Manajemen Mutu Sekolah (Stategi Peningkatan Mutu dan Daya Saing Lembaga Pendidikan Islam). Yogyakarta: Ar-Ruzz.

Menteri Pendidikan Nasional. (2007). Peraturan Menteri Pendidikan Nasional Republik Indonesia Nomor 24 Tahun 2007 tentang Standar Sarana prasarana Sekolah Dasar/Madrasah Ibtidaiyah (SD/MI), Sekolah Menengah Pertama/Madrasah Tsanawiyah (SMA/MTs) dan Sekolah Menengah Atas/ Madrasah Aliyah.

Putri, S. P. (2013). Sistem Informasi Laboratorium Berbasis Web pada SMA Negeri 4 Yogyakarta. Yogyakarta: STMIK Amikom.

Rahardjo, Adisasmita. 2011. Pengelolaan Pendapatan dan Anggaran Daerah. Yogyakarta: Graha Ilmu.

Presiden Republik Indonesia. (2005). Peraturan Pemerintah Republik Indonesia Nomor 19 tahun 2005 tentang standar nasional pendidikan.

Riswanto, R., \& Dewi, N. A. K. (2017).

Peningkatan Keterampilan Proses Sains Melalui Pembelajaran Berbasis 
Riswanto - Efektivitas Dan Efisiensi Sistem Inventaris...

Laboratorium

Untuk

Mewujudkan pembelajaran

Berkarakter. Jurnal Riset Dan

Kajian Pendidikan Fisika, 4(2),

60.

Susanto, Azhar. 2005. Sistem

Informasi Manajemen. Jakarta:

Ghaila Indonesia

Suseno, N., \& Riswanto, R. (2017).

Sistem

Pengelolaan

Laboratorium Fisika untuk

Mewujudkan Pelaksanaan

Praktikum Yang Efisien. Jurnal

Pendidikan Fisika, 5(1), 76-86. 